\title{
JUSTIÇA GRATUITA, ASSISTÊNCIA JUDICIÁRIA E ASSISTÊNCIA JURÍDICA: BREVES APONTAMENTOS
}

\author{
Eduardo Simões Neto ${ }^{1}$
}

\section{Resumo}

A história da concessão de assistência aos que não puderem arcar com os custos do processo é bastante antiga. Atualmente engloba a possibilidade de a parte necessitada não efetuar o pagamento das despesas decorrentes de relação jurídica processual, o patrocínio da causa por advogado sem custos e a prestação de serviços extrajudiciais gratuitamente.

O instituto deve ser interpretado de forma ampla, envolvendo todas as etapas do processo e o foro extrajudicial. O conceito de necessitado, por sua vez, deverá ser apurado diante do caso concreto, sendo que o simples fato de possuir patrimônio ou um bom emprego não o exclui automaticamente do conceito.

Apesar da importância da assistência judiciária é insuficiente em um cenário no qual muitos sequer sabem que possuem direitos. Assim, deve existir conjugada com uma forte política educacional.

Palavras-chave: direito de ação, justiça gratuita, assistência judiciária, assistência jurídica.

\section{INTRODUÇÃO}

Não há sociedade sem direito (ubi scietas ibi jus). E na vida em sociedade surgem conflitos que deverão ser solucionados de acordo com a ordem jurídica que resguarda as relações sociais, de preferência, com o mínimo de prejuízo e desgaste.

Se antes os conflitos eram solucionados diretamente pelos envolvidos por meio da autotutela, com o particular mais forte impondo a sua vontade perante o mais fraco, com o processo de fortalecimento do Estado este passou a substituir as partes no momento de solucionar os $\operatorname{conflitos}^{2}$. Assim, hoje, após longo processo de avanços, estagnações e retrocessos, a regra é a vedação à justiça privada, devendo os que tiverem direitos lesados ou ameaçados acionar o Estado para pleitear uma solução.

A história da concessão de assistência aos que não puderem arcar com os custos do processo é bastante antiga, podendo ser identificada já no Livro I, Título XVI, $\S 5^{\circ}$ do Digesto romano $^{3}$.

1 Advogado e Professor Universitário. http://lattes.cnpq.br/3651086470750576

2 A Lei das XII tábuas, ainda no século II AC, já previa a participação do Estado (Romano Arcaico) na solução dos litígios.

3 "Deverá dar advogado aos que o peçam, ordinariamente às mulheres, ou aos pupilos, ou aos de outra maneira débeis, ou aos que estejam em juízo, se alguém os pedir; e ainda que não haja nenhum que os peça, deverá dá-lo de ofício. Mas se alguém disser que, pelo grande poder de seu adversário, não encontrou advogado, igualmente providenciará para que lhe dê advogado. Demais, não convém que ninguém seja oprimido pelo poder do seu

Revista da Faculdade Mineira de Direito, v.13, n. 25, jan./jun. 2010 - ISSN 1808-9429. 94 
No Brasil o surgimento do instituto da se confunde com a própria colonização.

A assistência se desenvolve, evolui, e hoje pode ser separada em três institutos que não se confundem. Justiça gratuita significa a possibilidade de a parte necessitada não efetuar o pagamento das despesas decorrentes de relação jurídica processual. É, portanto, um conceito negativo: a dispensa de pagamento de custas e demais despesas. Assistência judiciária remete ao patrocínio da causa de forma gratuita por advogado pertencente à organização que pode ser estatal ou para-estatal. A atuação deve ser contínua (não-eventual) e disponibilizada para toda a sociedade, sob pena de configurar mero favor isolado. A assistência jurídica é conceito amplo e que engloba assistência judiciária e a prestação de serviços extrajudiciais, como, exempli gratia, serviços consultivos, elaboração de contratos, notificações extra-judiciais, etc., sendo, portanto, mais ampla.

O presente trabalho discorre sobre alguns dos diversos pontos polêmicos acerca desses institutos.

\section{ESTADO E INTERVENÇÃO}

A idéia de Estado exercendo a Jurisdição, como o poder de dizer o direito, não tive evolução linear, passado por longo e tumultuado processo de avanços e retrocessos. À guisa de exemplo, muitos séculos após o Digesto Romano facilitar o acesso ao Estado-juiz prevendo assistência gratuita por advogado foi exarado na China decreto pelo Imperador Hangs Hsi prevendo punição para todos que procurassem o Judiciário:

todos aqueles que se dirigirem aos Tribunais sejam tratados sem nenhuma piedade, sem nenhuma consideração, de tal forma que se desgostem tanto da idéia do Direito quanto se apavorem com a perspectiva de comparecerem perante um magistrado. Assim, o desejo para evitar que os processos não se multipliquem assombrosamente, o que ocorreria se não existe o temor de se ir aos Tribunais, o que ocorreria se os homens concebessem a falsa idéia de que teriam a sua disposição uma justiça acessível e ágil; o que ocorreria se pensassem que os juízes são sérios e competentes. Se essa falsa idéia se formar, os litígios ocorrerão em número infinito e a metade da população será insuficiente para julgar os litígios da outra metade. ${ }^{4}$

Nos EUA e Europa, com as Revoluções Burguesas do século XVIII, surgiu o paradigma liberal de Estado, omisso e não interventor, que tratava a todos de forma igual, independente das diferenças fáticas e reais. De fato,

adversário, pois também redunda em desprestígio do que governa uma província, que alguém se conduza com tanta insolência que todos temam tomar a seu cargo advogado contra ele".

4 SENA, Adriana Goulart de. Rev. Trib. Trab. 3ª Reg., Belo Horizonte, v. 46, n 76, p.93-114, jul-dez.2007, p.109, citando SPRENKEL, Van Der. Legal Institucions in Machú China. 1962, p. 77.

Revista da Faculdade Mineira de Direito, v.13, n. 25, jan./jun. 2010 - ISSN 1808-9429. 95 
[...] o pensamento liberal de análise da sociedade e de gestão da economia e das próprias políticas públicas constitui-se na primeira corrente de pensamento a alcançar a efetividade hegemonia na história do capitalismo, desde a afirmação desse sistema socioeconomico a partir do século XVIII. ${ }^{5}$

$\mathrm{E}$

Foi por meio dessas revoluções que se firmou o 'declínio do absolutismo, do mercantilismo e dos resquícios do regime feudal [...]' e a ascensão de um novo modelo de Estado, fundado na '[...] prática do individualismo econômico e no liberalismo político [...]', o Estado Liberal de Direito. ${ }^{6}$

O poder passou a ser visto como inimigo da liberdade burguesa. Os direitos fundamentais se limitavam, assim, a uma conduta negativa do Estado, que deveria permanecer estranho ao mercado econômico, de trabalho e demais relações particulares. Devendo o Estado se abster de prestar, tem-se terreno infértil para o desenvolvimento da assistência judiciária.

O juiz, mera 'boca da lei', se mantinha preso ao texto legal, em nova forma de absolutismo, agora não mais centrado no Rei, mas no Parlamento.

No Estado Liberal de Direito, os parlamentos da Europa continental reservaram a s o poder político mediante a fórmula do princípio da legalidade. Diante da hegemonia do parlamento, o executivo e o judiciário assumiram posições óbvias de subordinação. $\mathrm{O}$ executivo somente poderia atuar se autorizado pela lei e nos seus exatos limites, e o judiciário apenas aplicá-la, sem mesmo poder interpretá-la; o legislador, assim, assumia posição nítida de superioridade. Na teoria da separação dos poderes, a criação do direito era tarefa única e exclusiva do legislativo.

[...] o poder dos juízes ficaria limitado a afirmar o que já havia sido dito pelo legislativo, pois o julgamento deveria ser apenas "um texto exato da lei". Por isso, Montesquieu acabou concluindo que 'o poder de julgar' era, de qualquer modo, um 'poder nulo' (en quelque façon, nulle)'.

Na época atuava a chamada escola exegética, que, além de ter sido influenciada pelo iluminismo, foi acentuadamente marcada pelo positivismo jurídico e, assim, pela déia de submissão do juiz à lei.

A jurisdição, mergulhada no sistema de Chiovenda, é vista como função voltada à atuação da vontade contrata da lei.

Chiovenda é um verdadeiro adepto da doutrina que, inspirada no iluminismo e nos valores da Revolução Francesa, separava radicalmente as funções do legislador e do juiz, ou melhor, atribuía ao legislador a criação do direito e ao juiz a sua aplicação. ${ }^{7}$

5 DELGADO, Maurício Godinho. Capitalismo, trabalho e emprego: entre o paradigma da destruição e os caminhos da reconstrução. São Paulo: LTr, 2006, p. 56/46

6 DELGADO, Gabriela Neves. Direito fundamental ao trabalho digno. São Paulo: LTr, 2006, p. 29

7 MARINONI, Luiz Guilherme. Curso de direito processual civil. Vol.1. Teoria geral do processo. $3^{\text {a }}$ Ed. 2008. São Paulo, RT, 2008, p. 26-36.

Revista da Faculdade Mineira de Direito, v.13, n. 25, jan./jun. 2010 - ISSN 1808-9429. 96 
Nesse contexto de absoluta vedação à qualquer forma de prestação positiva por parte do Estado a idéia de assistência aos desamparados por meio de isenção de custas ou mesmo prestação de serviços de advocacia se torna impopular.

A igualdade formal agravou a desigualdade real, de modo que o Estado liberal, essencialmente contraditório, ruiu.

A idéia de Estado é repensada em função do reconhecimento da necessidade de se assegurar um bem estar social (Welfare State), somente atingível através de sua intervenção para efetivar no mundo fenomênico a igualdade idealizada, fala-se em direitos positivos, "de crença" na atuação estatal. Surge o Estado Social, que "por sua própria natureza, é um Estado intervencionista, que requer sempre a presença militante do poder político nas esferas sociais" ${ }^{8}$, como uma forma de adaptação do Estado Liberal. O conceito de igualdade, arrastado com tal evolução, abarcou a idéia de que medidas positivas do Estado, mais do que possibilidades, são necessidades para que exista real igualdade.

Os direitos não surgem pensados após arquitetos jurídicos se debruçarem sobre a sociedade e pensarem acerca das suas necessidades. Surgem de acordo as necessidades que, diariamente, se impõem ao Estado. A sua construção, paulatina, traz respostas às práticas e violências existentes. Preenche os espaços e vazios. De fato,

\footnotetext{
a liberdade de ir e vir se reposta à Bastilha (...), a liberdade de escrever e de imprimir lembra Emílio queimado pelas mãos do carrasco e Rousseau banido por um dos mais belos livros do século; a liberdade de consciência lembrava os protestantes expulsos do Reino e destituídos de estado civil. A propriedade confirmada como direito natural respondia às velhas dívidas feudais às quais ela havia sido subjugada (...) a igualdade diante da lei se opunha Às justiças excepcionais; a igual admissibilidade dos encargos aos privilégios dos graus reservados aos nobres; a partilha proporcional dos impostos à taille - imposto cobrado dos plebeus. ${ }^{9}$
}

Com a falência do paradigma Liberal de Estado ganhou força a idéia de um Estado que deve atuar de forma positiva em diversos situações e contextos para assegurar que as partes, em situação de desigualdade fática, possam defender seus direitos.

Essa criação de diversos direitos sociais para assistir aqueles despossuídos de poder econômico e político favorece a ampliação da assistência jurídica, tema do presente trabalho.

Hodiernamente, no Brasil, a regra é, indubitavelmente, a solução dos conflitos através da jurisdição, pois nenhuma lesão ou ameaça de lesão terá sua apreciação excluída do Poder

8 BONAVIDES, Paulo. Do Estado Liberal ao Estado Social. $5^{\text {a }}$ ed. rev. e ampl. Belo Horizonte: Del Rey, 1993, p. 196.

9 JANET, Paul. Philosophie de la Revolution Francaise. 4a. Ed. Paris. 1892, t. I, p. XLVI. Citado por

MORANGE, Jean. Direitos Humanos e Liberdades Públicas. 5a. ed. rev. e ampl. Barueri, SP: Manole, 2004, p. 19.

Revista da Faculdade Mineira de Direito, v.13, n. 25, jan./jun. 2010 - ISSN 1808-9429. 97 
Judiciário. Podem, entretanto, as partes resolver o conflito através de outras formas de hetercomposição, como, por exemplo, a arbitragem, possível para direitos indisponíveis. Também podem compor sem a intervenção de terceiros (autocomposição) e, apenas quando expressamente autorizados ${ }^{10}$, defender-se pela autotutela (exemplo: artigos 578, 644 e 1210, $\S$

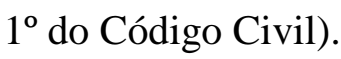

A Constituição de República Federativa do Brasil, de inegável feição social, prevê no art. 5\%, LXXIV, que "o Estado prestará assistência jurídica integral e gratuita aos que comprovarem insuficiência de recursos". A assistência judiciária, por sua vez, está expressamente disciplinada pela Lei n. ${ }^{\circ} 1.060$ de 05 de fevereiro de 1950 , em vigor eis que recepcionada pela ordem constitucional vigente.

O direito "não flutua em um espaço vazio, mas liga-se a um quadro social, político, econômico, institucional do país" ${ }^{11}$. De acordo com a teoria da indivisibilidade dos direitos fundamentais o conceito de indivíduo ultrapassa o paradigma liberal, sendo o conjunto de direitos sociais referência para a concretização de todos os demais. O direito ao trabalho, por exemplo, deve ser compreendido em sua significação ética: trabalho, como elemento que concretiza a identidade social do homem, possibilitando-lhe autoconhecimento e plena socialização.

Em função da interdependência e complementaridade dos direitos e garantias fundamentais não existe a possibilidade de se assegurar acesso ao judiciário sem investimento em educação, pois,

(...)a falta de recursos vem, muitas vezes, acompanhada da falta de informação, o acesso à justiça é obstado até mesmo pelo dato do pobre desconhecer que tenha direitos a pleitear ou que possa ter sucesso na tarefa de lutar por seus direitos. A barreiras culturais, são na verdade, mais difíceis de serem vencidas do que as barreiras econômicas. Estas podem ser afastadas isentando-se o carente das despesas com o processo e fornecendo-lhe gratuitamente um advogado para patrocinar seus interesses. As barreiras culturais só serão afastadas de fato na medida em que nível sociocultural da população evoluir. ${ }^{12}$

10 O Código Penal tipifica o exercício arbitrário das próprias razões nos arts. 345 e 346, que assim dispõem: Art. 345 - Fazer justiça pelas próprias mãos, para satisfazer pretensão, embora legítima, salvo quando a lei o permite:

Pena - detenção, de quinze dias a um mês, ou multa, além da pena correspondente à violência. Parágrafo único - Se não há emprego de violência, somente se procede mediante queixa.

Art. 346 - Tirar, suprimir, destruir ou danificar coisa própria, que se acha em poder de terceiro por determinação judicial ou convenção:

Pena - detenção, de seis meses a dois anos, e multa.

11 MEDAUAR, Odete. Direito Administrativo Moderno. 5 ed. rev. e atual. São Paulo: Revista dos Tribunais, 2001. P.

12 MARCACINI, Augusto Tavares Rosa. Assistência Jurídica, Assistência Judiciária e Justiça Gratuita. Rio de Janeiro: Forense, 2001. P.22.

Revista da Faculdade Mineira de Direito, v.13, n. 25, jan./jun. 2010 - ISSN 1808-9429. 98 
Destarte, não deve o Estado se limitar a prestar serviços gratuitos para ingresso e atuação perante o Poder Judiciário, mas também investir em educação, essencial até mesmo para que o cidadão possa identificar a existência de direitos.

\section{ASPECTOS POLÊMICOS}

\subsection{O Alcance da Expressão de Necessitado}

De acordo com o parágrafo único do art. $2^{\circ}$ da Lei 1.060 de 05 de fevereiro de 1950, “considera-se necessitado, para os fins legais, todo aquele cuja situação econômica não lhe permita pagar as custas do processo e os honorários de advogado, sem prejuízo do sustento próprio ou da família”, critério que só pode ser compreendido por meio de análise de situação concreta. Exempli gratia: um salário mensal de R\$ 2.000,00 (dois mil reais) pode ser suficiente para o sustento de um jovem estudante que resida com pais que possuam situação econômica estável, mas insuficiente para um trabalhador que possua três dependentes.

Possuir patrimônio também não importa em automática justificativa para que se indefira a assistência jurídica, pois não se pode exigir que o jurisdicionado venda o seu patrimônio para custeio do processo. Ademais, não se pode ignorar a existência de proprietários endividados, desempregados e sem renda fixa para manter sua família. Destarte, poderá gozar o benefício ainda que possuidor de patrimônio não vultoso. É o que se extrai, verbi gratia, do seguinte julgamento do Egrégio Tribunal Regional do Trabalho de Minas Gerais $^{13}$ :

Necessitado dos benefícios da assistência judiciária é todo aquele que não tem condições econômicas para pagar as custas do processo e os honorários do advogado, sem prejuízo do sustento próprio ou de sua família, pouco importando que possua imóvel residencial, automóvel e linha telefônica. Agravo provido.

O patrimônio, desde que atenda a função social, goza ainda de proteção constitucional.

Pelos mesmos argumentos, a ocupação de cargo público ou a conclusão de curso superior não impedem a concessão do benefício o exercício do comércio (excetua-se o médico, contra quem milita presunção relativa de possibilidade de suportar os custos do seu processo).

Também milita contra o deferimento da justiça gratuita gasto com operação cirúrgica meramente estética, em função de tratar-se de procedimento meramente supérfluo. 


\subsection{Foro extrajudicial}

Não é razoável limitar o acesso do necessitado a apenas alguns dos instrumentos jurídicos necessários ao exercício da cidadania.

Assim, mesmo que não se trate de foro judicial, é possível a concessão da gratuidade para obter certidões, averbações, etc.

\subsection{Pessoas Jurídicas}

A lei 1060/50 considera como "necessitado, para os fins legais, todo aquele cuja situação econômica não lhe permita pagar as custas do processo e os honorários de advogado, sem prejuízo do sustento próprio ou da família” (Parágrafo único do art. $2^{\circ}$ ).

A expressão "sem prejuizo do sustento próprio ou da família” embasou entendimento de que as pessoas jurídicas não podem gozar dos benefícios ora analisados. A análise meramente gramatical da lei realmente conduz a tal conclusão. Entretanto, não se deve analisar um dispositivo com base em critério meramente gramatical. Ora, podem-se vislumbrar hipóteses de pessoa jurídicas desprivilegiadas que necessitem de tratamento diferenciado sob pena de não conseguirem defender seus direitos em juízo.

As expressões "sustento" e "família", por sua vez, podem significar bens essenciais à sobrevivência dos sócios e dos empregados. Como se não bastasse, há na Constituição expressa menção à livre iniciativa e o tratamento favorecido para as empresas de pequeno porte (art. 170), indo, em sentido contrário a tal determinação, a imposição de barreiras ao acesso ao Poder Judiciário.

Os institutos podem, assim, alcançar a pessoa jurídica.

\subsection{Do Pagamento ao final do Processo em função de Alteração Fática Relevante}

Prevê o art. 12 da Lei 1060/50 que

a parte beneficiada pelo isenção do pagamento das custas ficará obrigada a pagá-las, desde que possa fazê-lo, sem prejuízo do sustento próprio ou da família, se dentro de cinco anos, a contar da sentença final, o assistido não puder satisfazer tal pagamento, a obrigação ficará prescrita.

Revista da Faculdade Mineira de Direito, v.13, n. 25, jan./jun. 2010 - ISSN 1808-9429. 100 
Exemplificando: se uma parte obtém ganho com o processo que melhore visivelmente a sua capacidade econômica, poderá arcar com custos dos honorários periciais. É o que se extrai de decisão do Tribunal Regional do Trabalho de Minas Gerais ${ }^{14}$ :

\begin{abstract}
JUSTIÇA GRATUITA - HONORÁRIOS PERICIAIS - ART. 790-B DA CLT INTERPRETAÇÃO. A Lei n. 10.537/02, publicada em 28-8-02, acrescentou na CLT o art. 790-B, livrando da responsabilidade pelo pagamento dos honorários periciais o beneficiário da Justiça Gratuita. O dispositivo, porém, não contém regra absoluta, devendo ser interpretado à luz do princípio da razoabilidade, tendo em conta o desfecho da causa. A solução será distinta, conforme o empregado reclamante, cuja miserabilidade legal tenha sido reconhecida, saia total ou parcialmente vencedor na demanda. Se todos os pedidos forem julgados improcedentes, a situação de penúria mantém-se inalterada, não sendo exigível o pagamento dos honorários periciais. $\mathrm{O}$ mesmo não ocorre, porém, se o empregado sair parcialmente vencedor na demanda, fazendo jus a valores em pecúnia. Nessa hipótese, é razoável e justo que esses créditos sejam utilizados, ainda que parcialmente, para a quitação dos honorários do perito. Esse entendimento encontra amparo no art. 12 da Lei n. 1.060/50.
\end{abstract}

Um alerta: apesar da redação do artigo 12, não se trata verdadeiramente de um prazo prescricional eis que não houve inércia da parte interessada, mas sim inexistência de condição capaz de gerar a possibilidade de cobrança das custas, a saber, alteração da situação fática do beneficiário.

\title{
3.5. Caução na Ação Rescisória
}

Determina o inciso II art. 488 do Código de Processo Civil que, ao ajuizar uma Ação Rescisória, deverá a parte depositar 5\% (cinco por cento) sobre o valor da causa, a título de multa, caso a ação seja, por unanimidade de votos, declarada inadmissível, ou improcedente. Senão vejamos:

\footnotetext{
Art. 488. A petição inicial será elaborada com observância dos requisitos essenciais do art. 282, devendo o autor:

I - cumular ao pedido de rescisão, se for o caso, o de novo julgamento da causa;

II - depositar a importância de 5\% (cinco por cento) sobre o valor da causa, a título de multa, caso a ação seja, por unanimidade de votos, declarada inadmissível, ou improcedente.

Parágrafo único. Não se aplica o disposto no no II à União, ao Estado, ao Município e ao Ministério Público.
}

Pode a parte ajuizar ação rescisória eximindo-se de tal depósito em função de gratuidade da justiça?

Parte da doutrina entende que a parte, por não dispor de meios de arcar com tal depósito, fica liberada de fazê-lo, sob pena de afronta à igualdade e ao livre acesso ao Poder

14 TRT - 00056-2004-111-03-00-1 RO, Data de Publicação 31/03/2005 DJMG, Página: 11, Órgão Julgador Sexta Turma, Relator Convocada Olívia Figueiredo Pinto Coelho, Revisor Lucilde D'Ajuda Lyra de Almeida.

Revista da Faculdade Mineira de Direito, v.13, n. 25, jan./jun. 2010 - ISSN 1808-9429. 
Judiciário (RJTJ-SP, vol. 98, p.394 e vol. 102, p. 375, RT vol. 546, p. 157 e vol. 584, p. 150). Há, entretanto, quem advogue tese contrária a isenção, em função de o manejo da ação rescisória dever ser sempre desestimulado (RT vol. 602, p. 144 e vol. 619, p.142).

Não podemos concordar com a segunda posição, pois, embora a ação rescisória realmente seja excepcional e não deva ser estimulada, a gratuidade da justiça não pode permitir que o cidadão litigue em apenas determinadas circunstâncias, devendo o beneficio ser concedido independente do tipo de ação ou objeto.

Contudo, ocorrendo as hipóteses descritas no inciso II deverá o Autor depositar a multa prevista em função da isonomia e, até mesmo, penalidade pela má utilização da perigosa ação rescisória.

Coerente com o entendimento ora defendido prevê o art. 836 da CLT, com redação dada pela Lei 11.495/07, o depósito de $20 \%$ do valor da causa, "salvo prova de miserabilidade jurídica do autor”. Senão vejamos:

\begin{abstract}
Art. 836. É vedado aos órgãos da Justiça do Trabalho conhecer de questões já decididas, excetuados os casos expressamente previstos neste Título e a ação rescisória, que será admitida na forma do disposto no Capítulo IV do Título IX da Lei no 5.869, de 11 de janeiro de 1973 - Código de Processo Civil, sujeita ao depósito prévio de $20 \%$ (vinte por cento) do valor da causa, salvo prova de miserabilidade jurídica do autor.
\end{abstract}

A Consolidação das Leis do Trabalho, além de dispensar o depósito na seara trabalhista em caso de miserabilidade do Autor, mostra que a tendência é, realmente, assegurar amplo acesso à Justiça.

\title{
3.6. Altos Salários
}

O art. $4^{\circ}$ da Lei 1060, com redação dada pela Lei 7.510 de 1986 , determina que "a parte gozará dos benefícios da assistência judiciária, mediante simples afirmação, na própria petição inicial, de que não está em condições de pagar as custas do processo e os honorários de advogado, sem prejuízo próprio ou de sua família”.

$\mathrm{O}$ art. $5^{\circ}$, por sua vez, determina que "o juiz, se não tiver fundadas razões para indeferir o pedido, deverá julgá-lo de plano, motivando ou não o deferimento dentro do prazo de setenta e duas horas".

Flagrante o escopo da Lei de facilitar a concessão.

Com base em tais dispositivos a grande maioria dos Juízes concede o pedido de assistência jurídica ao desempregado mesmo diante da comprovação de ter recebido durante 
vários anos salários significativos, em certos casos superiores até mesmo ao teto do funcionalismo público.

Julgados isolados Justiça do Trabalho, entretanto, entendem na que se a parte laborou durante anos no cargo de "Gerente Geral” de agência bancária, mesmo estando desempregada no momento da distribuição da ação, obteve ganhos incompatíveis com a Justiça Gratuita.

Em função do que já dissemos sobre a impossibilidade de se exigir que a parte aliene o seu patrimônio para ingressar em juízo, entendemos que do desemprego se extrai presunção favorável à concessão da assistência jurídica, independente do cargo e salário anteriores.

\subsection{Revogação do art. 11 da lei 1060/50 pelo art. 20 do CPC}

É comum a aplicação do art. 11 da lei 1060/50 pelos nossos Tribunais. Entretanto, data venia, o referido artigo foi revogado pelo art. 20 do Código de Processo Civil. Senão vejamos:

Lei 1060/50

Art. 11. Os honorários de advogados e peritos, as custas do processo, as taxas e selos judiciários serão pagos pelo vencido, quando o beneficiário de assistência for vencedor na causa.

$\S 1^{\circ}$. Os honorários do advogado serão arbitrados pelo juiz até o máximo de $15 \%$ (quinze por cento) sobre o líquido apurado na execução da sentença.

$\S 2^{\circ}$. A parte vencida poderá acionar a vencedora para reaver as despesas do processo, inclusive honorários do advogado, desde que prove ter a última perdido a condição legal de necessitada.

CPC

Art. 20. A sentença condenará o vencido a pagar ao vencedor as despesas que antecipou e os honorários advocatícios. Esta verba honorária será devida, também, nos casos em que o advogado funcionar em causa própria.

$\S 1^{\circ} \mathrm{O}$ juiz, ao decidir qualquer incidente ou recurso, condenará nas despesas o vencido.

$\S 2^{\circ}$ As despesas abrangem não só as custas dos atos do processo, como também a indenização de viagem, diária de testemunha e remuneração do assistente técnico. $\S$ $3^{\circ}$ Os honorários serão fixados entre o mínimo de dez por cento $(10 \%)$ e o máximo de vinte por cento (20\%) sobre o valor da condenação, atendidos:

a) o grau de zelo do profissional;

b) o lugar de prestação do serviço;

c) a natureza e importância da causa, o trabalho realizado pelo advogado e o tempo exigido para o seu serviço.

$\S 4$ o Nas causas de pequeno valor, nas de valor inestimável, naquelas em que não houver condenação ou for vencida a Fazenda Pública, e nas execuções, embargadas ou não, os honorários serão fixados consoante apreciação eqüitativa do juiz, atendidas as normas das alíneas a, b e c do parágrafo anterior.

§ 5o Nas ações de indenização por ato ilícito contra pessoa, o valor da condenação será a soma das prestações vencidas com o capital necessário a produzir a renda correspondente às prestações vincendas (art. 602), podendo estas ser pagas, também mensalmente, na forma do $\S 20$ do referido art. 602, inclusive em consignação na folha de pagamentos do devedor. 


\title{
3.8. Da Remuneração dos profissionais estranhos ao Estado (advogados, peritos, tradutores, extratores de fotocópias, etc.)
}

O princípio da isonomia processual determina que as partes sejam tratadas de forma igual na relação processual, gozando das mesmas oportunidades para atingir os fins que lhes interessam. Essencial, para tanto, que possam produzir provas que dêem suporte às suas pretensões.

Ora,

\begin{abstract}
Assim como não tem sentido deixar a assistência previdenciária a cargo da generosidade dos médicos, também não parece correto deixar a assistência judiciária gratuita a cargo dos advogados. (RTJ 115/878).
\end{abstract}

Assim, se o processo demandar a atuação de terceiros (como advogados, tradutores, peritos, etc.) deverá o profissional ser remunerado pelo Estado, desde que não receba normalmente deste para desempenhar tais tarefas. Noutras palavras: deve o Estado arcar com todos os custos necessários para um justo desenvolvimento procedimental do processo (custos pela extração de fotocópias, tradução pública, perícias, etc.). $\mathrm{O}$ entendimento possui razoável aceitação:

RSTJ 109/205: cabe ao Estado arcar com os honorários periciais.

ASSISTÊNCIA JUDICIÁRIA - Salário de perito - Pagamento - Isenção -Obrigação integral do Estado - Art. $5^{\circ}$, inc. LXXIV, da Constituição da República - Recurso provido. (RJTJ-SP 125/296.)

Há, entretanto, entendimento no contrário de que não deve o poder público pagar honorários a patronos de carentes não integrantes dos serviços públicos de assistência.

\subsection{Litigância de má-fé}

Possuindo interesse provas da condição econômica satisfatória de quem requer o benefício indevidamente a outra parte pode (e deve) pleitear o seu indeferimento. E, de acordo com o $\S 1^{\circ}$ do art. $4^{\circ}$, comprovado de que a parte requereu o benefício possuindo meios de arcar com os custos do processo, poderá ser penalizada com o "pagamento até o décuplo das custas judiciais".

\subsection{Da natureza da decisão que aprecia o pedido}

Determina o art. 17 da Lei ${ }^{\circ} 1.060$, de 5 de fevereiro de 1950, com redação dada pela Lei $\mathrm{n}^{\circ}$ 6.014, de 1973, que “caberá apelação das decisões proferidas em conseqüência da 
aplicação desta lei; a apelação será recebida somente no efeito devolutivo quando a sentença conceder o pedido".

Entretanto, tendo em vista tratar-se de mero incidente processual e não decisão terminativa, parte da doutrina entende que, apesar da determinação legal, a decisão deve ser atacada através de agravo.

A questão na é inteiramente pacífica, existindo decisões que negaram seguimento a Agravo por considerarem o manejo de tal recurso "erro grosseiro" que impede a fungibilidade (RJTJ-SP vol. 98, p. 314).

Em sentido contrário, existem decisões não conhecendo de apelações (RT, vol. 577, p. 250, vol. 630, p. 126, vol. 590, p. 145 e vol. 606, p. 131).

Há quem entenda que a decisão desafia apelação e "somente na hipótese do art. 5", caput, da Lei $n .^{\circ} 1.060 / 50$ ” que prevê a possibilidade de o Juiz, se não tiver fundadas razões para indeferir o pedido, deverá julgá-lo de plano, motivando ou não o deferimento dentro do prazo de setenta e duas horas. Caso a decisão não seja exarada em tal hipótese, seria “adequado o agravo” (RSTJ, vol. 36, p. 347 e vol. 40, p. 563).

Em função da cizânia existente jamais haverá nesse caso "erro grosseiro", devendo, portanto se utilizar o princípio da fungibilidade dos recursos.

\subsection{Procuração com poderes específicos para requerer}

Existe entendimento entendendo que o requerimento de Justiça Gratuita só pode ser formulado por procurador com poderes específicos. Senão vejamos:

JUSTIÇA GRATUITA. Na Justiça do Trabalho, para a concessão da Justiça Gratuita ao empregado, é necessário que ele perceba salário igual ou inferior ao dobro do mínimo legal ou comprove situação de miserabilidade jurídica, mediante declaração de próprio punho, ou firmada por procurador com poderes específicos para isso (inteligência do artigo 789, parágrafo 9o.,da CLT, c/c artigo 14, parágrafo 1o., da Lei 5.584/70, e artigo 4o. da Lei 1060/50, com redação dada pela Lei 7.510/86). Não havendo nenhuma prova dessa condição, improcede o benefício da Justiça Gratuita. Condenado o reclamante ao pagamento das custas processuais e não efetuado o recolhimento respectivo, resulta deserto o recurso por ele interposto. (TRT-3a REGIÃO , RO - 868/01, Data de Publicação 04/04/2001, DJMG Página: 25, Órgão Julgador Segunda Turma, Relator Alice Monteiro de Barros)

AGRAVO DE INSTRUMENTO. DESERÇÃO. Se o reclamante afirma estar vivendo de biscates não se pode presumir que a sua remuneração mensal seja igual ou inferior ao limite de dois salários mínimos fixado pela Lei 5.540/70 (art. 14). Logo, seria indispensável para a obtenção do benefício da justiça gratuita que o empregado tivesse declarado o seu estado de miserabilidade. Declaração de pobreza feita por advogado que não possui poderes específicos para fazê-la não atende às exigências da Lei 7.115/83 e conseqüentemente inviabiliza o deferimento do benefício. Agravo de instrumento desprovido. 
(TRT-3a REGIÃO , AI - 700/99, Data de Publicação 26/11/1999, DJMG Página: 3, Órgão Julgador Seção Especializada, Relator Alice Monteiro de Barros)

Trata-se de entendimento minoritário, entendendo a maioria da doutrina que basta requerimento por parte do Autor, sem quaisquer formalidades adicionais.

\section{DIREITO COMPARADO - O CASO ESPANHOL}

Dispõe Constituição Espanhola que "a justiça será gratuita quando assim dispuser a lei, e, em todo caso quanto se acredite haver insuficiência de recursos para litigar" ${ }^{, 15}$.

No mesmo sentido assegura o art. 24 da Constituição da Itália de 1947 que os menos favorecidos devem, por lei, possuir meios adequados para defenderem seus direitos em juízo. Senão vejamos:

Artigo $24^{\circ}$ [Direito de ser ouvido no Tribunal]

(1) Todos podem trazer casos perante um tribunal de direito, a fim de proteger os seus direitos ao abrigo do direito civil e administrativo.

(2) Defesa é um direito inviolável em todas as fases e exemplo de um processo judicial.

(3) Os pobres têm direito por lei de meios adequados para a ação ou defesa em todos os tribunais.

(4) A lei define as condições e formas de reparação em caso de erros judiciais.

A questão assume especial importância em países de $3^{\circ}$ mundo, nos quais a incapacidade de arcar com os custos do processo é mais freqüente. Exemplificando, mais de $70 \%$ dos angolanos não têm acesso aos serviços de justiça do país por razões econômicas, o que levou a Ordem dos Advogados de Angola (OAA) a promover conferência em 2007 para tratar da advocacia gratuita, assistência judiciária, a empresa em tribunal e a defensoria pública $^{16}$.

\section{CONCLUSÃO}

A assistência judiciária é apenas um dos recursos que deve ser utilizado para que o jurisdicionado sem recursos econômicos tenha assegurada a possibilidade de ingressar em juízo.

A sua importância faz com que a sua interpretação deva ser a mais extensa possível, sob pena de, eventualmente, se inviabilizar o direito dos que não tiverem recursos.

15 Tradução livre do seguinte dispositivo: “Artículo 119. A justiça será gratuita quando tal esteja previsto pela lei, e, em qualquer caso, quanto aqueles que não possuem recursos suficientes a acção judicial.”

16 http://www.ibinda.com/noticias.php?noticia=3683 Acessado em 26/09/09.

Revista da Faculdade Mineira de Direito, v.13, n. 25, jan./jun. 2010 - ISSN 1808-9429. 
Em função da interdependência e complementaridade dos direitos e garantias fundamentais, não se deve limitar a assegurar o acesso ao judiciário, sendo essencial que venha acompanhado de investimento em educação.

Mais do que mecanismos de acesso ao Poder Judiciário, a gratuidade de justiça, assistência judiciária e assistência jurídica são importantes instrumentos de inclusão social. Entretanto, para que as classes menos favorecidas realmente tenham seus direitos resguardados, deve existir investimento também nos demais direitos e garantias fundamentais, especialmente uma coerente política educacional.

\begin{abstract}
The history of legal assistance by the State to those who cannot afford the costs of a law suit is quite old. Currently evolves the possibility of not paying Court taxes, free legal advise and free legal services out of the Court.

The Institute should be interpreted broadly, involving all procedures and the services outside of a Courtroom. The concept of needed, however, can only be established before an actual case. Having goods a good job doesn't automatically exclude one person of the concept of needed.

Despite its importance, legal aid is not sufficient because a lot of times people don't even know they have rights. Therefore, there also be investments in education.
\end{abstract}

Keywords: right of action, gratuitous justice, legal aid, legal assistance.

\title{
REFERÊNCIAS
}

AGRA, Walber de Moura. Curso de Direito Constitucional. $3^{\text {a }}$ Ed. Rio de Janeiro: Forense, 2007.

BOBBIO, Norberto. A Era dos Direitos. Rio de Janeiro: Campus, 1996.

CAPPELLETTI, Mauro; GARTH, Bryant. Acesso à Justiça. Trad. Ellen Gracie Northfleet. Porto Alegre: Sergio Antonio Fabris, 1988.

CARVALHO, Kildare Gonçalves. Direito constitucional. $14^{a}$ ed. rev. atual. e ampl. Belo Horizonte: Del Rey, 2008, p, 82

DELGADO, Gabriela Neves. Direito fundamental ao trabalho digno. São Paulo: LTr, 2006.

DELGADO, Maurício Godinho. Capitalismo, trabalho e emprego: entre o paradigma da destruição e os caminhos da reconstrução. São Paulo: LTr, 2006.

DINAMARCO, Cândido Rangel. Instituições de direito processual civil. São Paulo: Malheiros, 2001.

Revista da Faculdade Mineira de Direito, v.13, n. 25, jan./jun. 2010 - ISSN 1808-9429. 107 
JANET, Paul. Philosophie de la Revolution Francaise. Paris. 1892.

JUNIOR, Nelson Nery. Princípios do Processo Civil na Constituição Federal. São Paulo, RT, $5^{\text {a Edição }}$

MAGALHÃES, José Luiz Quadros de. Direito Constitucional. Belo Horizonte:

Mandamentos, 2000.

MARCACINI, Augusto Tavares Rosa. Assistência Jurídica, Assistência Judiciária e Justiça Gratuita. Rio de Janeiro: Forense, 2001.

MARINONI, Luiz Guilherme. Curso de direito processual civil. Vol.1. Teoria geral do processo. $3^{\text {a }}$ Ed. 2008. São Paulo, RT, 2008.

MEDAUAR, Odete. Direito Administrativo Moderno. 5 ed. rev. e atual. São Paulo: Revista dos Tribunais, 2001.

MENDES. Gilmar Ferreira. Parecer 77, de 1994, referente à revisão da Constituição Federal, Diário dos Trabalhos Revisionais, julho /1994, p. 4.362

HORTA. Raul Machado. Direito Constitucional. 2a ed. Rev., atual, e ampl. Belo Horizonte. Editora Del Rey. 1999.

VIEIRA. Oscar Vilhena. A Constituição e sua Reserva de Justiça - um ensaio sobre os limites materiais ao poder de reforma. São Paulo. Malheiros. 1999. 